Primljen / Received: 3.10.2015. Ispravljen / Corrected: 14.8.2016. Prihvaćen / Accepted: 12.12.2016. Dostupno online / Available online: 10.7.2017.

\section{Experimental study of grouted sleeve lapping connector under tensile load}

Authors:

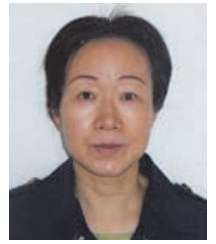

Yu Qiong, MSc.

Tongji University, China

Research Institute of Structural Engineering

and Disaster Reduction

yiongyu2005@163.com

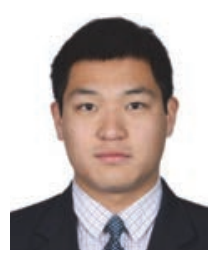

Xu Zhiyuan, MSc. CE

Tongji University, China

Research Institute of Structural Engineering and Disaster Reduction

zyxu_0908@163.com
Original scientific paper

\section{Yu Qiong, Xu Zhiyuan}

\section{Experimental study of grouted sleeve lapping connector under tensile load}

The performance of the grouted sleeve lapping connector that is used to connect reinforcement bars in a precast concrete structure is studied. A total of 63 specimens, varying in bar diameter and lap length, were tested under tensile load. The failure modes, ultimate tensile strength values and load-displacement curves of the specimens are discussed in the study. Two equations are proposed for calculating the average lapping bond stress and critical lap length.

Key words:

precast concrete structure, sleeve confinement, bond-slip; lap length

Izvorni znanstveni rad

Yu Qiong, Xu Zhiyuan

Eksperimentalno ispitivanje injektiranog prstenastog preklopnog spoja uslijed vlačnog opterećenja

U radu se analizira izvođenje injektiranog prstenastog spoja koji je korišten za spajanje armaturnih šipki u predgotovljenim betonskim konstrukcijama. Ispitana su ukupno 63 uzorka, koja su se razlikovala po promjeru šipki i duljini spoja uslijed vlačnog opterećenja. Istraživanjem je obuhvaćena vrsta sloma, granična vrijednost vlačne čvrstoće te dijagram opterećenja i progiba uzorka. Preporučena su dva izraza za proračun prosječnog naprezanja prstenastog spoja i kritične duljine spoja.

Ključne riječi:

predgotovljena betonska konstrukcija, ovijanje prstenastog spoja, prokliznuće prianjanja, duljina preklopa

Wissenschaftlicher Originalbeitrag

Yu Qiong, Xu Zhiyuan

Experimentelle Untersuchung der injizierten ringförmigen überlappenden Verbindung aufgrund der Zuglast

In der Arbeit wird die Ausführung einer injizierten ringförmigen Verbindung analysiert, die für die Verbindung von Bewehrungsstäben in vorgefertigten Betonkonstruktionen verwendet wird. Getestet wurden insgesamt 63 Proben, die sich im Durchmesser der Stäbe und der Länge der Verbindung aufgrund der Zuglast unterscheiden. Mit der Untersuchung wurde die Art des Bruches, der Grenzwert der Zugfestigkeit sowie das Belastungs- und Durchbiegungsdiagramm der Probe umfasst. Empfohlen wurden zwei Ausdrücke für die Berechnung der Spannung der Ringverbindung und der kritischen Verbindungslänge.

\section{Schlüsselwörter:}

vorgefertigte Betonkonstruktion, Einwickeln der Ringverbindung, Abgleiten der Adhäsion, Länge der Überlappung 


\section{Introduction}

Ever since the grouted splice invented by Alfred A. Yee [1] in the late 1960s was applied to connect reinforcement bars in the precast column of a hotel in Hawaii [2], numerous efforts have been made to develop splices to join reinforcement bars. Based on the theories illustrated in previous studies [3-7], many grouted splices in which bars were spliced in line were invented [1, 8-15]. However, the construction of the sleeve was rather complicated, and manufacturing was relatively expensive. To improve confinement and restrain development of cracks, the internal diameter of the sleeve was usually small. Because of manufacturing and construction errors, the tilt stub rod could not sometimes be inserted into the sleeve in the process of construction.

The grouted metal corrugated pipe splice [16] was another connection that was used to connect bars in precast concrete, as shown in Figure 1. The stub rod of the inferior precast concrete shear wall was inserted into a metal corrugated pipe in the upper precast concrete shear wall. Afterwards, grout was poured into the metal corrugated pipe, and the two walls were connected through the anchorage between the stub rod and grout. The bar anchorage length of the grouted metal corrugated pipe splice was too long.

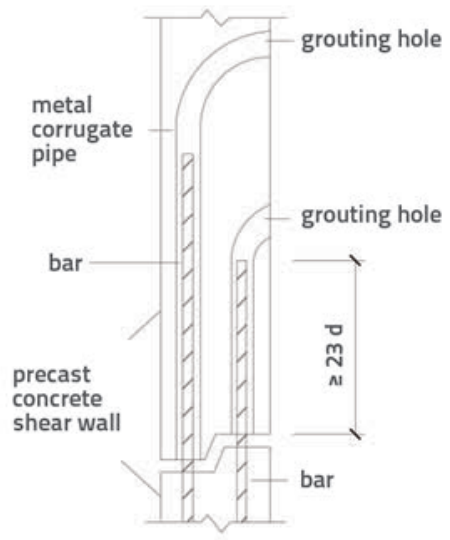

Figure 1. Sketch map of grouted metal corrugated pipe splice

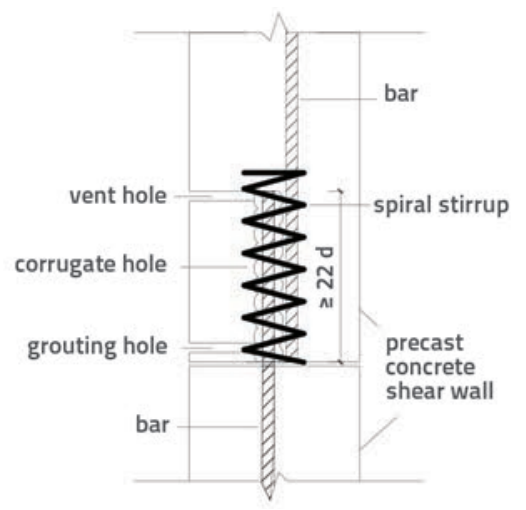

Figure 2. Sketch map of plug-in filling hole for steel bar lapping connection
The plug-in filling hole for steel bar lapping (Figure 2) was invented by Jiang et al [17] and it proved to be suitable for precast concrete structure reinforced connections [18]. The development of cracks surrounding the anchorage region was controlled by surrounding the lapping splice with transverse reinforcement [19-21], but the lap length was still too long.

By surrounding the lapping splice with a sleeve, confinement could be produced along the lapping bars [22-24], and cracks around the bars could be restrained. In this way, the lap length could be reduced by a large margin. A grouted sleeve lapping connector [25] placed two bars adjacent to each other over a sufficient length to transfer stress entirely from one bar to another through grout. A hollow cylindrical standard steel pipe was set around the lapping splice to provide confinement of grout and restrain development of cracks. A sketch of the grouted sleeve lapping connection that was used to splice bars in precast concrete shear walls is shown in Figure 3.

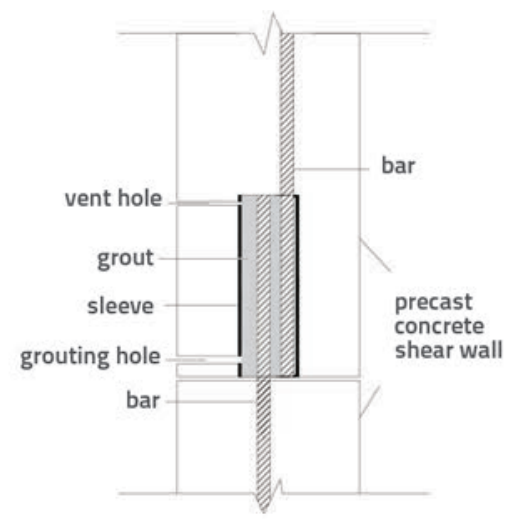

Figure 3. Sketch map of grouted sleeve lapping connection

In this study, the grouted sleeve lapping connector was tested experimentally with the bar diameter and bar lap length varying among the specimens. The load transfer mechanism and mechanical properties of the grouted sleeve lapping connector were analysed, and a recommended lap length was given.

\section{Experimental program}

A test program was carried out on 63 grouted lapping sleeve connectors with various bar diameters and lap lengths to understand the effects of the interacting variables and confinement mechanism.

\subsection{Specimens}

A hollow cylindrical standard steel pipe was fixed by spot welding it to a reinforcement bar called welded bar (the purpose of spot welding one bar to the sleeve is to fix the steel pipe, thus simulating the construction of the connector in a real structure). Another reinforcement bar called inserted bar was placed adjacent to the welded bar. The lap length of the bars equalled the length of the pipe. No-shrinkage grout was poured 
into the sleeve to anchor the two reinforcing bars. The working performance of the grouted sleeve lapping connector in which the bars were placed clinging to each other was poorer than the connector in which certain space existed between the two bars, as more grout was present between the two bars, and larger mechanical interlock between grout keys and bar ribs prevented the bars from slipping in the latter connector. Specimen details are shown in Figure 4.

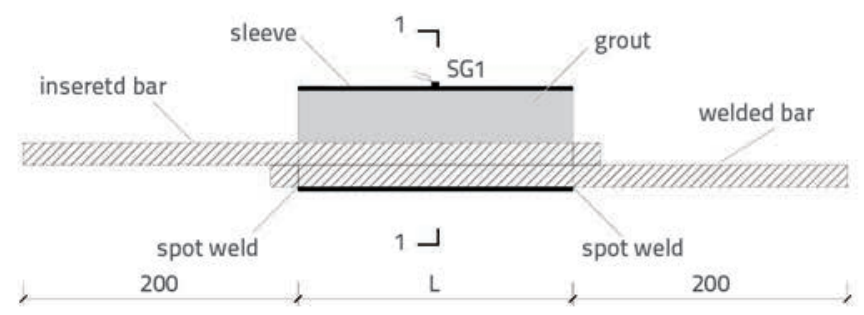

at the rate of $100 \mathrm{~mm} / \mathrm{min}$ until bar failure. The flexural strength, compressive strength, and tensile strength of the grout amounted to 11.4 MPa, 62.9 MPa and 4.63 MPa, respectively.

\subsection{Test plan and setup}

A strain gauge (SG1) was installed transversely on the sleeve at the mid-point of the lap length to evaluate the confining pressure exerted by the sleeve on the grout that eccentrically surrounds the splice length, as shown in Figure 4.

The specimens were tested under an incremental tensile load generated by a hydraulic actuator. The welded bar was clamped by the fixed end, whereas the inserted bar was gripped by the loading end, as shown in Figure 5. The length of specimens between the grippers equalled the sum of lap length and $200 \mathrm{~mm}$. The loading system of the specimens was the same as that of the control bar. The load-displacement curves and strains were recorded.

\section{Test results}

The adjacent alignment of the welded bar and inserted bar led to eccentricity. More specifically, the welded bar and inserted bar is placed clinging to each other, not in a line (Figure 6.a). Under
Specimen dimensions are given in Table 1. Steel pipes $70 \mathrm{~mm}$ in internal diameter and $3 \mathrm{~mm}$ in thickness, with a nominal yield strength of $235 \mathrm{~N} / \mathrm{mm}^{2}$, were used to splice the adjacent bars. The sleeve lengths, $L$, were 8,10 and 12.5 times the bar diameters, which ranged from $12 \mathrm{~mm}$ to $25 \mathrm{~mm}$. Each group with a specified bar diameter and the corresponding lap length contained 3 identical specimens.

\subsection{Material properties}

Control bars with a nominal yield strength of $400 \mathrm{~N} / \mathrm{mm}^{2}$ were tested to evaluate material properties (Table 2). The free length of control bars between grippers amounted to approximately $350 \mathrm{~mm}$. The initial loading velocity was $2 \mathrm{kN} / \mathrm{s}$. After the tensile stress exceeded the yielding threshold of the bar, $450 \mathrm{MPa}$, the incremental tensile load was applied
Table 2. Material properties of the control bars

\begin{tabular}{|c|c|c|c|c|c|c|c|}
\hline Bar diameter, $\boldsymbol{d}[\mathrm{mm}]$ & 12 & 14 & 16 & 18 & 20 & 22 & 25 \\
\hline Average yield strength $\mathrm{f}_{\mathrm{y}, \mathrm{c}}\left[\mathrm{N} / \mathrm{mm}^{2}\right]$ & 423 & 418 & 407 & 452 & 421 & 444 & 448 \\
\hline Average ultimate tensile strength, $\mathrm{f}_{\mathrm{u}, \mathrm{c}}\left[\mathrm{N} / \mathrm{mm}^{2}\right]$ & 570 & 577 & 572 & 625 & 615 & 562 & 585 \\
\hline
\end{tabular}
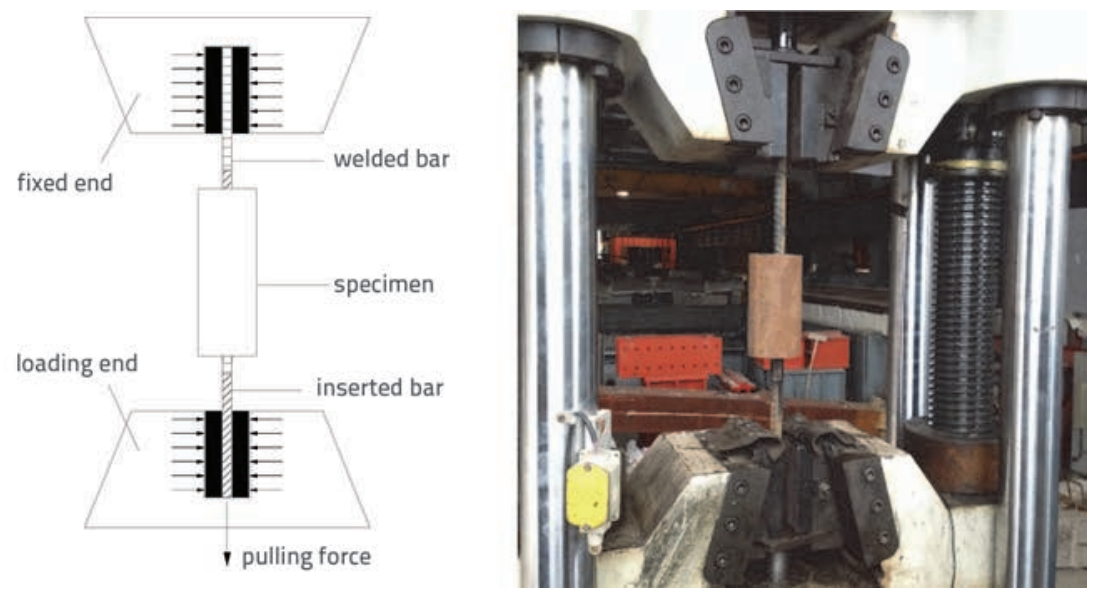

Figure 5. Setup of tensile test 
the tensile load $\mathrm{P}$, bending moment acting on the medium line $M=P \cdot d / 2$ is generated, leading to the rotation of the sleeve, as shown in Figure 6.b.

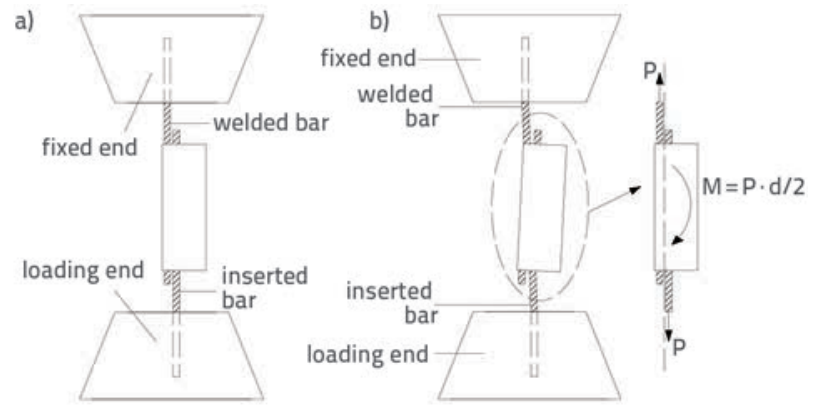

Figure 6. Deflection of specimen after test: a) before test; b) after test

\subsection{Load-displacement curves}

The load-displacement response of specimens is shown in Figure 7. Displacement, namely the displacement of grippers of the machine, was recorded by the computer to which the machine was connected. The measurement of displacement resulted in the initial concave shape of all load-displacement curves, denoting some slippage of bars from gripping. The tensile strength was higher than the yield strength, and plastic deformation developed with different degrees, indicating that all specimens failed in a ductile manner.

For specimens with lap lengths of 10 and 12.5 times the bar diameter, the bar-grout bond capacity outperformed tensile capacity of the overlapped bars, resulting in tensile fracture of the bar (either the spot welded or inserted bar). The development of load-displacement curves of the specimens was basically similar to that of the bare bar in tension.

The bar tensile fracture and the bar-grout bond failure were typical modes of failure for the specimens with the lap length 8 times the bar diameter. For the specimens that failed by bar-grout slip, the tensile strength of overlapped bars was higher than the bond strength between the bar and grout. The development of load-displacement curves for the grout-bar bond failure of specimens was different from the specimens exhibiting the bar tensile failure: after the tensile capacity reached its peak value, the curve declined suddenly as the bar
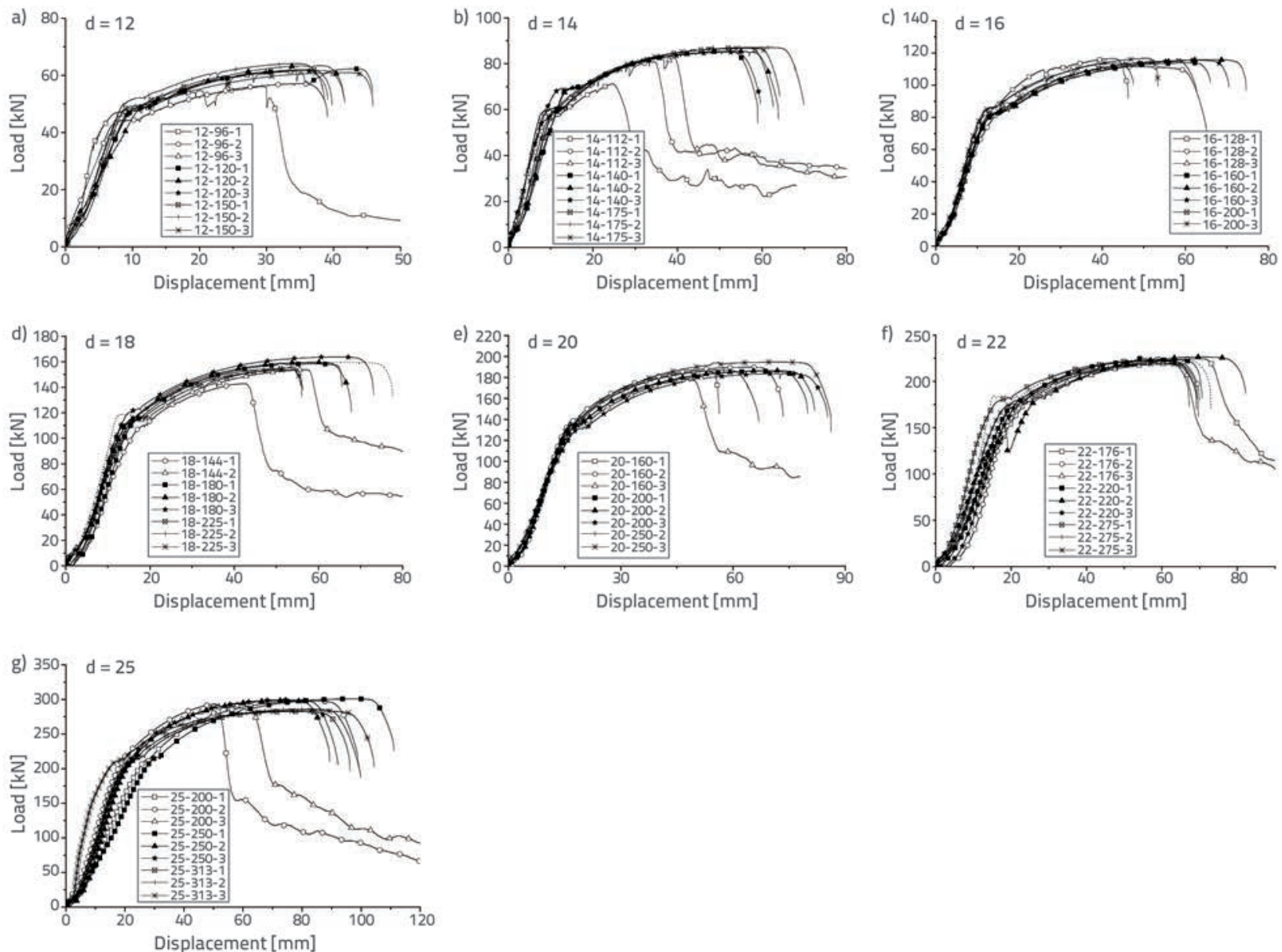

Figure 7. Load-displacement curves for bars diameter from 12 to $25 \mathrm{~mm}$ 
began to slip. Subsequently, large displacement developed with respect to a small decrement of load until the embedded bar slipped out of the grout. Different failure modes appeared in the same series of specimens because the lap length of $8 \mathrm{~d}$ seems to be a critical threshold at which the bare bar fracture out of the sleeve and the bar-grout bond failure may occur simultaneously.

\subsection{Failure modes}

The failure mode of all specimens is shown in Table 3. Figure 8.a and Figure 9.a show typical failure modes of the specimens: spot welded or inserted bar tensile fracture and grout-bar bond failure (either inserted bar or spot welded bar). The sleeve tensile failure and grout-sleeve bond failure do not appear. With the absence of longitudinal restraint, a part of the grout at the bottom of the sleeve was drawn out by mechanical interlocking between the grout keys and bar ribs when the bar was stretched and elongated, as shown in Figure 8.b, Figure 8.c, Figure 9.b, and Figure 9.c. Due to sleeve deflection, the welded bar tilted outwards and was extruded from the sleeve, as can be seen in Figure 8.b and Figure 9.b. The grout around the inserted bar was extruded and spalled off because of the tilt of the inserted bar, as shown in Figure 8.c and Figure 9.c. Hence, the spalling depth of grout at the sleeve bottom close to the loading end became greater than that at the sleeve bottom close to the fixed end.

\subsection{Evaluation of strength and ductility}

The ultimate tensile capacity, $P_{u^{\prime}}$ and ultimate tensile strength, $f_{u^{\prime}}$ are shown in Table 3 . The ultimate tensile strength of the specimens failing by bar fracture (Table 3 ) was close to the average tensile strength of the control bar (Table 2) with the same bar diameter. The following acceptance criteria for mechanical splices are recommended in ACl-318 12.14.3.2 [26]: the tensile strength of the splice, $f_{u^{\prime}}$ should be at least $125 \%$ the nominal yield strength of the spliced bar, $f_{y, b}\left(400 \mathrm{~N} / \mathrm{mm}^{2}\right)$. Thus, the strength ratio, $R_{s^{\prime}}$ which is expressed in Equation (1), should be at least 1.25 . The ultimate tensile strength, $f_{u^{\prime}}$ is calculated using Equation (2).

$$
R_{s}=\frac{f_{u}}{f_{y, b}}
$$

$f_{u}=\frac{4 P_{u}}{\pi d^{2}}$

The above specimen strength criteria are considered met if the value of $R_{\mathrm{s}}$ is greater than 1.25. Otherwise, the evaluation criteria are not satisfied. For example, as the value of $R_{\mathrm{s}}$ of specimen $12-96-2$ is greater than 1.25 , specimen $12-96-2$ meets the criteria. The value of $R_{\mathrm{s}}$ and strength rating of all specimens are shown in Table 3. We define displacement ductility as

$$
m=\delta_{u} / \delta_{y}
$$
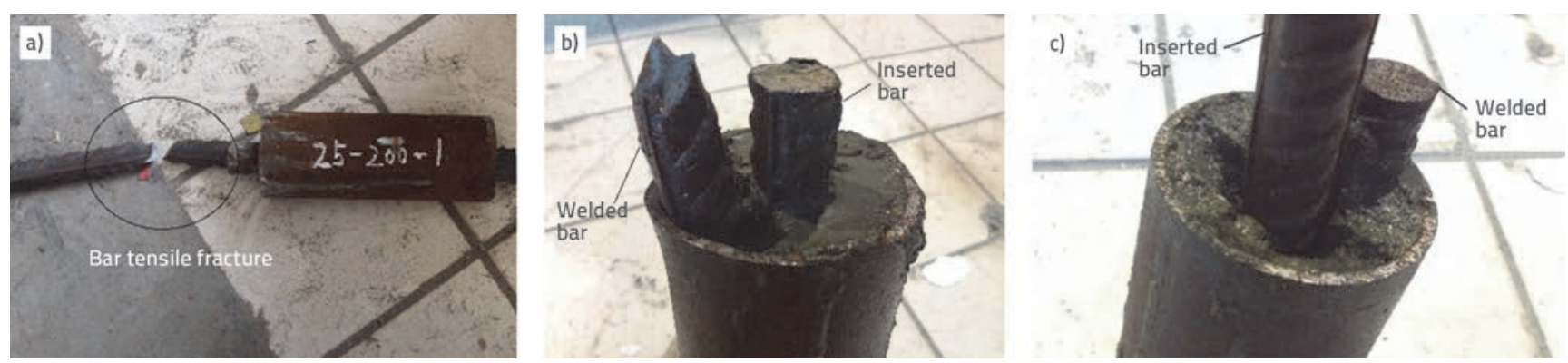

Figure 8. Bar tensile fracture: a) bar tensile fracture; b) grout damage appeared at the sleeve bottom near the fixed and; c) grout damage appeared at the sleeve bottom near the loading end
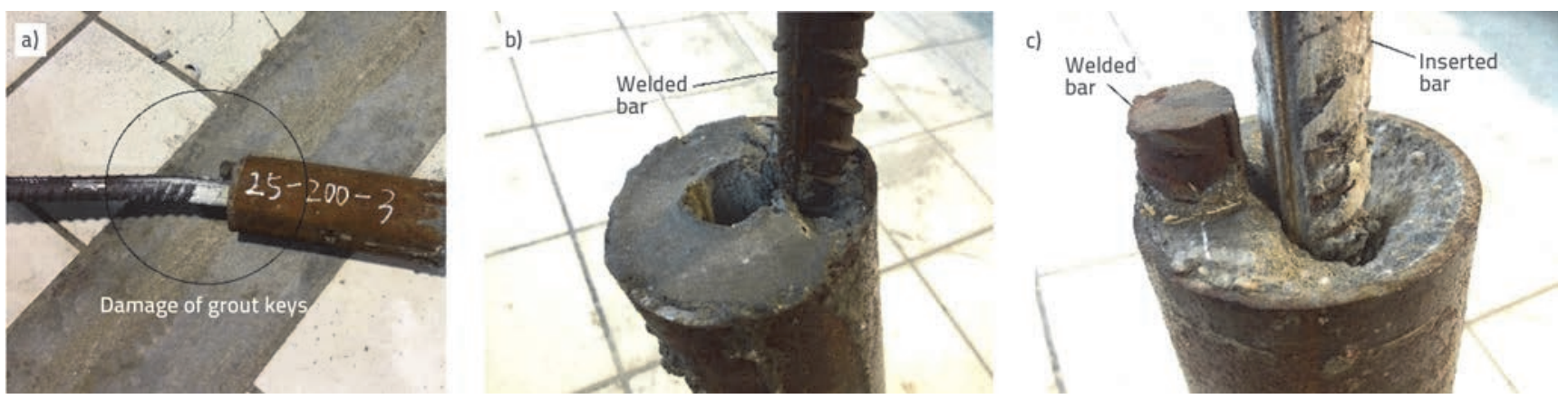

Figure 9. Bar-grout bond failure: a) bar-grout slip; b) grout damage appeared at the sleeve bottom near the fixed end; c) grout damage appeared at the sleeve bottom near the loading end 
Table 3a. Tensile load results, L/d = 8

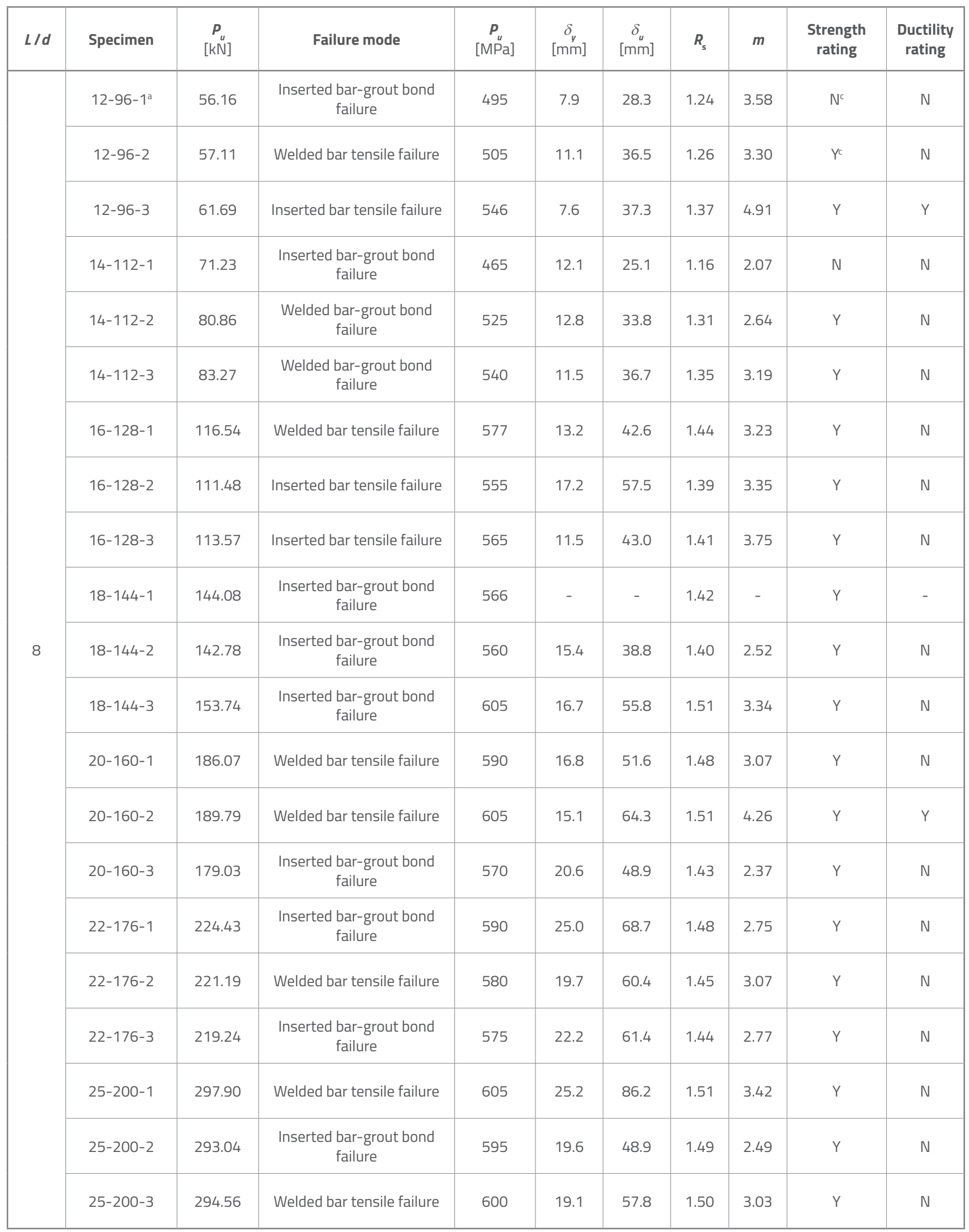


Table 3b. Tensile load results, $\mathrm{L} / \mathrm{d}=10$

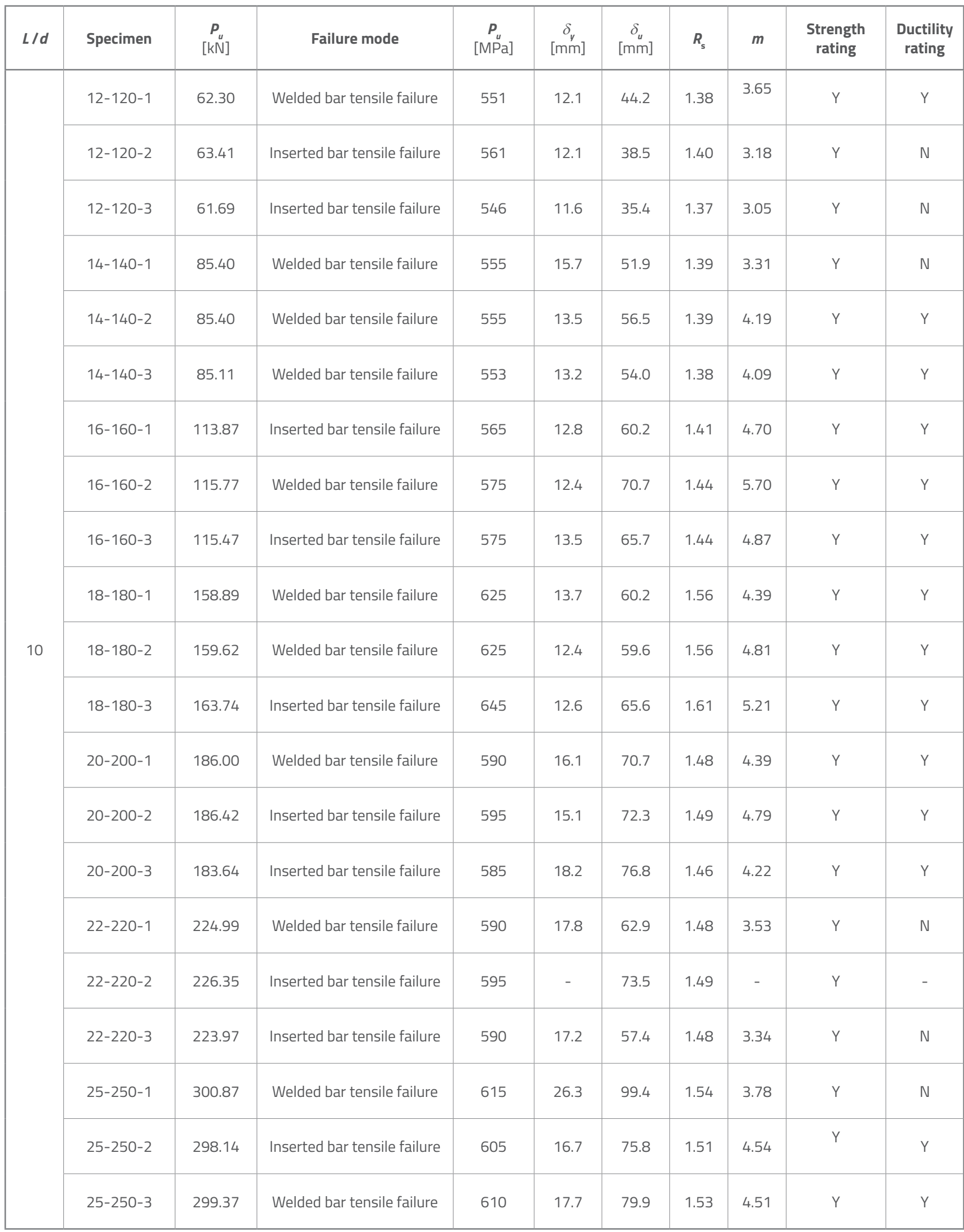


Table 3c. Tensile load results, $\mathrm{L} / \mathrm{d}=\mathbf{1 2 , 5}$

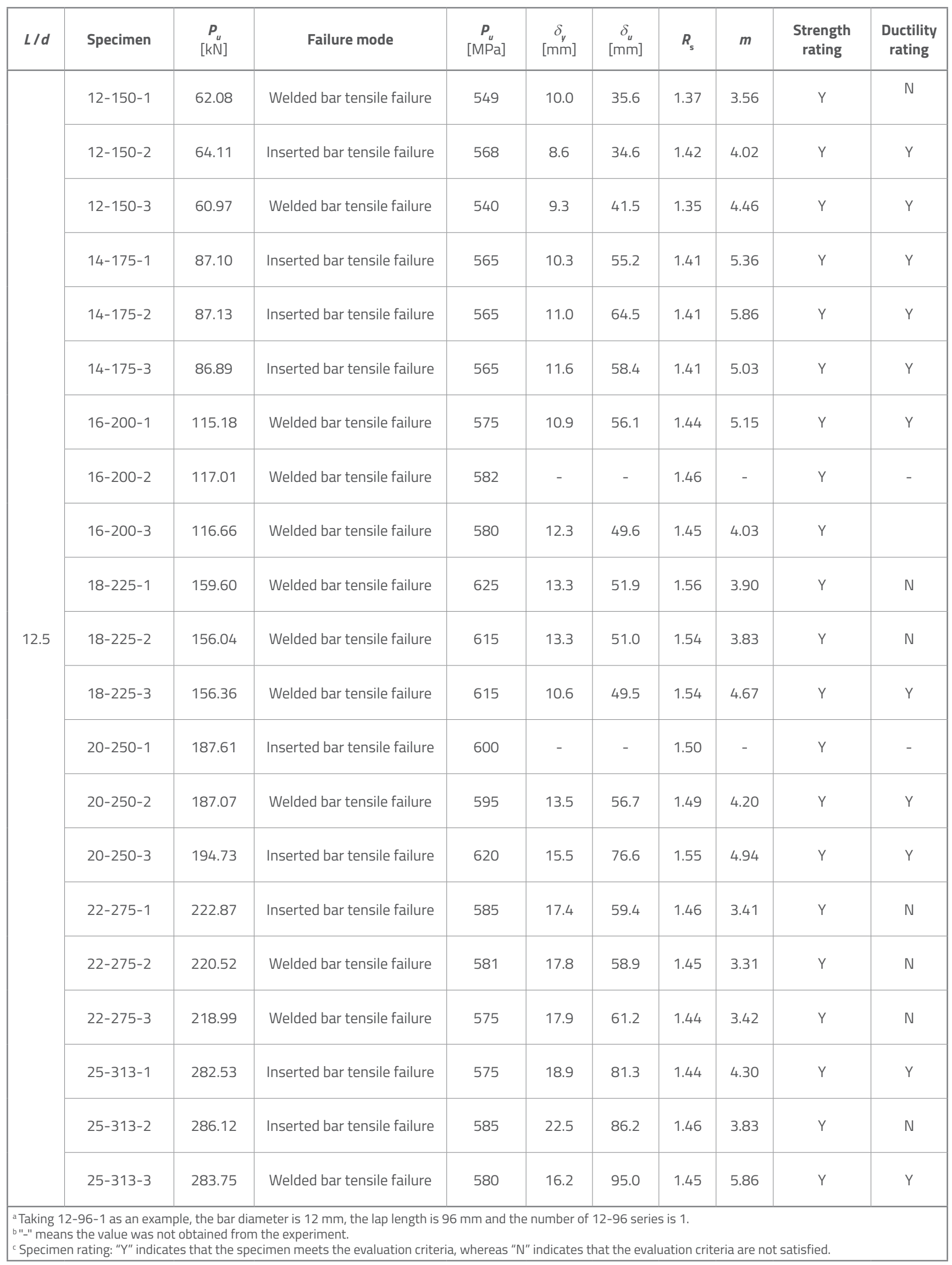


where $\delta_{u}$ is the displacement where the peak load occurred (or was sustained) and $\delta_{y}$ is the yield displacement. In order to determine a more accurate ductility factor value from the presented measurement results, the load-displacement curves are moved to the left by an amount defined by the intersection of the initial elastic slope with the abscissa of displacement, and so the revised load-displacement curves are obtained (Figure 10). The values of $\delta_{u}$ and $\delta_{y}$ are obtained from the revised loaddisplacement curves. According to recommendations given in paper [27], the ductility requirement of a structure in lowmoderate seismic regions should be at least 4.0. The value of $m$ being greater than 4.0 means that the specimen ductility meets the above criteria, otherwise, the evaluation criteria are not considered satisfied. For example, as the value of $m$ of specimen 12-96-3 is greater than 4.91, specimen 12-963 meets the criteria. The value of $m$ and ductility rating of all specimens is shown in Table 3. As can be seen in Table 3, the values of $m$ of almost all specimens with the lap length 8 times the bar diameter, and many specimens with the lap length 10 , 12.5 times the bar diameter, are less than 4.0 because of sleeve rotation. Thus, it is necessary to tests seismic behaviour of pre- cast shear walls with vertical reinforcement spliced by a grouted sleeve lapping connector to evaluate the operating performance of the grouted sleeve lapping connector used in the structures.

\section{Behaviour of grouted sleeve lapping connector}

\section{1. Load transfer mechanism}

Bonding force studies conducted by Lutz and Gergely in 1967 show that the bond of deformed bars is made up of three components: chemical adhesion, friction, and mechanical interlock between concrete and the bar [28]. In the beginning, the bond between reinforcement bars and grout primarily depends on chemical adhesion action, $\tau_{g^{\prime}}$ and the value of the sleeve confinement stress is nearly zero, as shown in Figure 11.a. Where bars-grout slip occurs, the friction and mechanical interlock between grout keys and bar ribs prevent the bars from slipping out of grout. The ribs split the grout by wedging action. Consequently, diagonal cracks appear above the bar ribs, and develop with an increasing pulling force. At the same time,
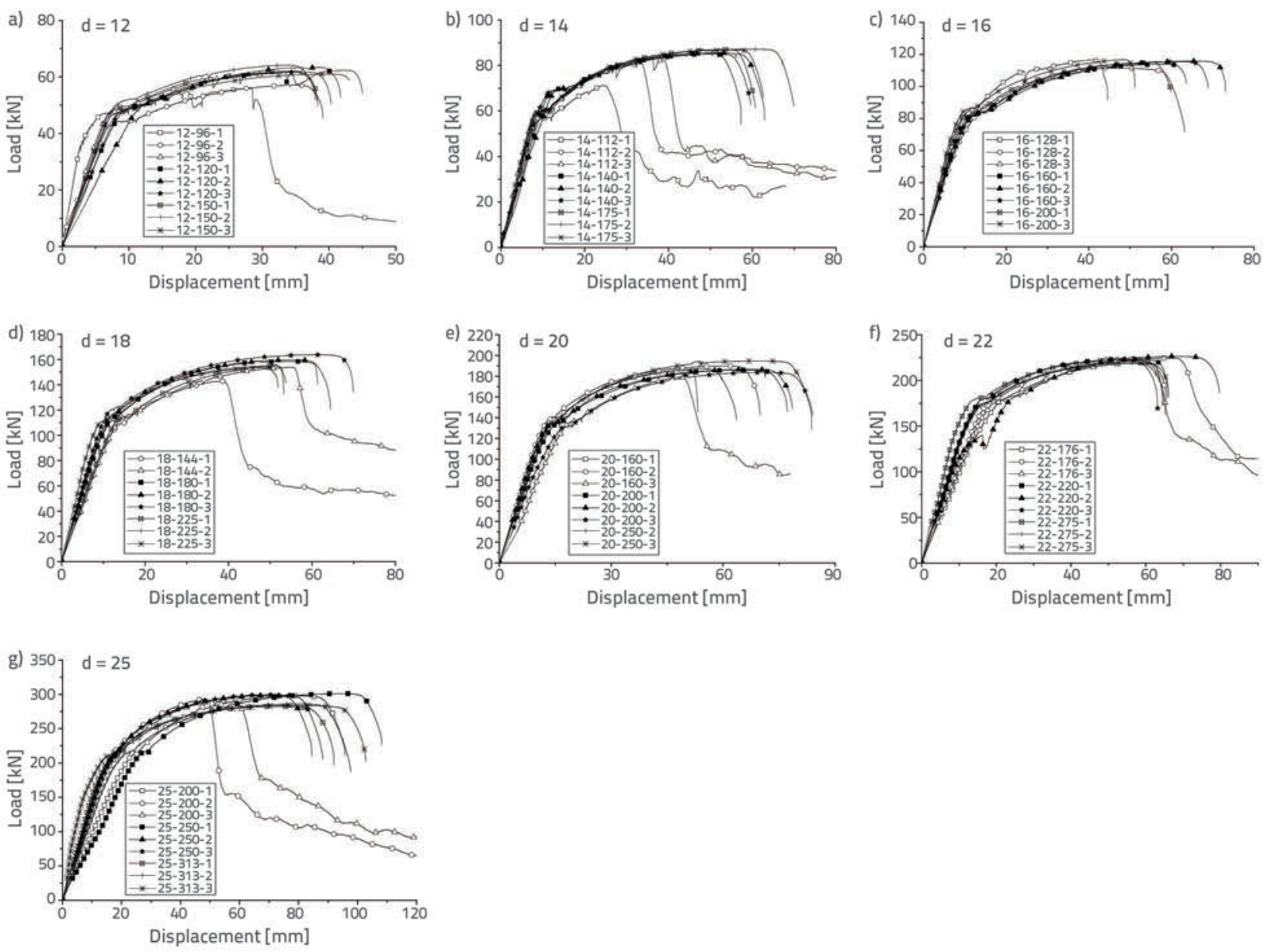

Figure 10. Revised load-displacement curves for bars diameter from 12 to $25 \mathrm{~mm}$ 

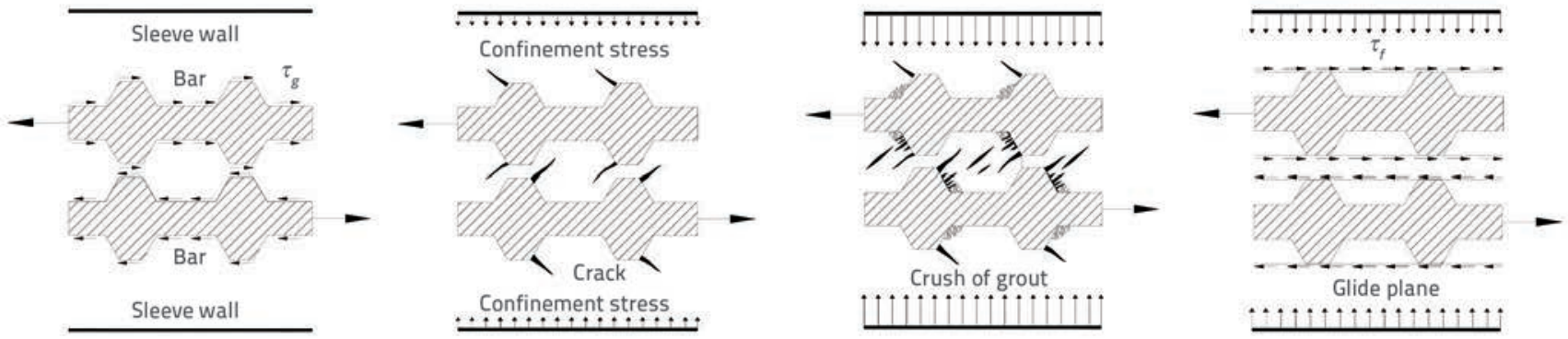

Figure 11. Load transfer mechanism of grouted sleeve lapping connector: a) Chemical adhesion; b) Diagonal cracks above bar ribs; c) Crush of grout; d) Bar slippage

the confinement stress generated by the sleeve wall works to restrain development of cracks. The process is illustrated in Figure 11.b. Because of confinement stress, the formation of splitting cracks demonstrated in previous studies [29-30] does not appear in the grouted sleeve lapping connector. As the pulling force increases, cracks develop and grow in the length, width and number. When grout is crushed to a "compacted powder", it becomes lodged in front of the ribs [31] (Figure 11.c). A glide plane forms immediately after the grout keys between the bar ribs are snapped, i.e. at the moment when the pulling force equals the bar-grout bond capacity and the confinement stress reaches its maximum. Afterwards, the bar slips out of grout. The process is shown in Figure 11.d. The sleeve confinement stress in all of the above mentioned bond stages provides resistance to control splitting of the grout and, consequently, improves mechanical interlock between grout keys and bar ribs. In this way, the tensile capacity of the grouted sleeve lapping connector is improved considerably.

\subsection{Mechanical characteristic}

In a certain range of lap length, the tensile capacity increases with an increase in lap length. As observed in specimen 18144-1 and in specimens from series 18-180-1, the average ultimate tensile capacity, $P_{u^{\prime}}$ increased from $144.08 \mathrm{kN}$ to $158.89 \mathrm{kN}$ when the lap length, $L$, increased from $144 \mathrm{~mm}$ to $180 \mathrm{~mm}$. As the lap length increases, more bar ribs are engaged in interlocking with grout keys. As a result, a larger total shear area of the grout keys is engaged to resist the pull-out force, and a higher bond stress is generated in the sleeve [24].

For specimens with the same bar diameter that failed by bar fracture, the ultimate tensile capacities are basically the same (as shown in Table 3). As the lap length increases, the average maximum value of the transverse tensile strain of the sleeve $\bar{\varepsilon}_{1, \mathrm{f}}$ as measured by SG1, decreases. If specimens $20 \mathrm{~mm}$ in bar diameter are taken as an example, the values of $\bar{\varepsilon}_{1, \mathrm{f}}$ obtained from the test of the specimens of series 20-160, 20-200, and $20-250$ are $595 \times 10^{-6}, 400 \times 10^{-6}$, and $41 \times 10^{-6}$, respectively. As the lap length increases, more bar ribs are engaged in interlocking with the grout keys, leading to a decrease in average bond strength. Consequently, the confinement provided by the sleeve wall decreases, presenting a decrease in the value of $\bar{\varepsilon}_{1, \mathrm{f}}$.
The variation of $\bar{\varepsilon}_{1, \mathrm{f}}$ with $L$ is shown in Figure 12 . All values of are lower than $1000 \times 10^{-6}$, which means that the sleeve provides a certain safety margin.

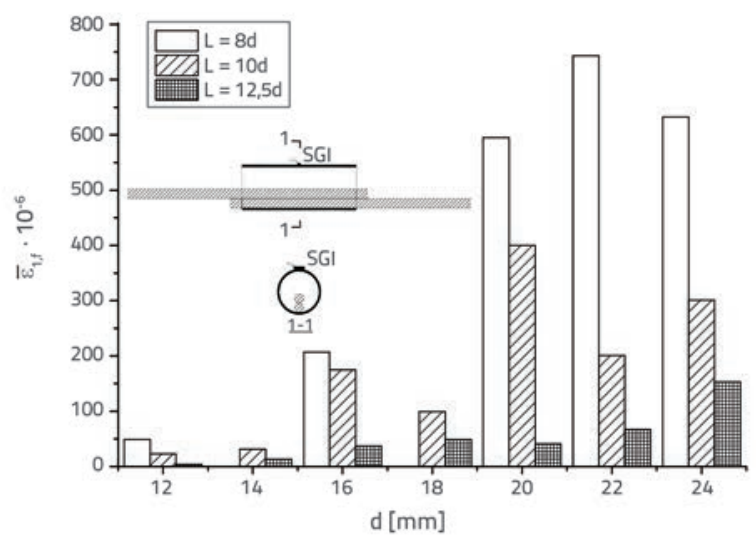

Figure 12. Variation of $\bar{\varepsilon}_{1, \mathrm{f}}$ with $L$ of specimens that failed by bar fracture

Figure 13 illustrates variation of the average maximum transverse tensile strain of the sleeve, $\bar{\varepsilon}_{1, f}$, with $d$ of the specimens failing by grout-bar bond failure. With the sleeve internal diameter invariant, an increase of the bar diameter leads to an increase in the confinement stress generated by the sleeve wall, corresponding to an increase in the value of $\bar{\varepsilon}_{1, f}$. This can be explained by the following two factors:

a) increase of effective sleeve area with respect to grout area makes the sleeve wall stronger and more able to resist the splitting expansion of grout, and

b) decrease in the stress absorption property of grout as limited allowable deformability is provided by a thin layer of grout surrounding the spliced bars, which subsequently makes the confinement response to the sleeve sensitive to splitting expansion of grout [24].

This mechanical characteristic can also be explained by the following theory: In axisymmetric problems of continuum mechanics, the strain-displacement relations are expressed in polar coordinates: $\varepsilon_{\mathrm{r}}=\mathrm{d} u_{\mathrm{r}} / \mathrm{d} r$ and $\varepsilon_{\theta}=u_{\mathrm{r}} / r$, where $u_{\mathrm{r}}$ is the radial displacement and $r$ is the radius from the line of axisymmetry [32]. For a sleeve of constant diameter, a higher bar size engages a smaller area of grout in radial compression and hoop tension; 
hoop tension is balanced by the confinement provided by the sleeve. Thus, the smaller the distance between the bar and the confinement, $r$, the higher the strain, $\varepsilon_{\theta^{\prime}}$ the latter develops.

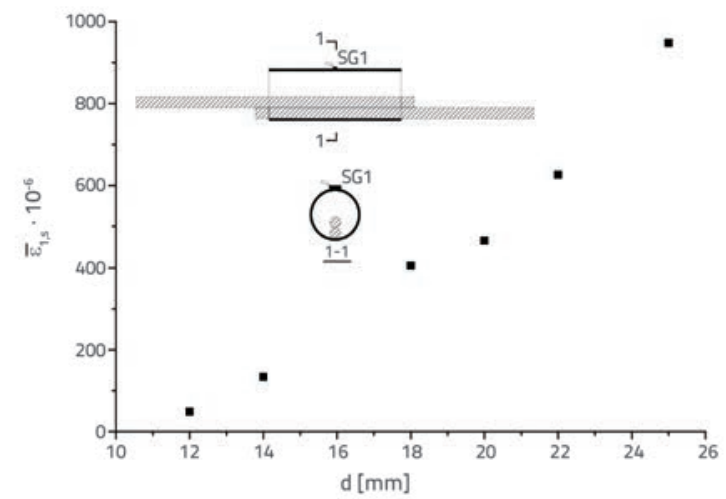

Figure 13. Variation of with $d$ of specimens that failed by grout-bar bond failure

\subsection{Analysis of lapping bond stress}

The average ultimate lapping bond stress, $\tau_{u^{\prime}}$ of the specimens that failed by grout-bar bond failure is defined as the ultimate tensile capacity divided by the product of the perimeter and the lap length (Equation (4)).

$\tau_{u}=\frac{P_{\mathrm{u}}}{\pi d L}$

Equation (5) applies for the specimens failed by grout-bar bond failure.

$L=8 d$

Equation (6) is derived by combing Equation (4) with Equation (5).

$\tau_{u}=\frac{1}{8 \pi} \frac{P_{\mathrm{u}}}{d^{2}}$

The parameters used in the experiments are substituted into Equation (6) and the variation of with $d$ is obtained, as shown in Figure 14.

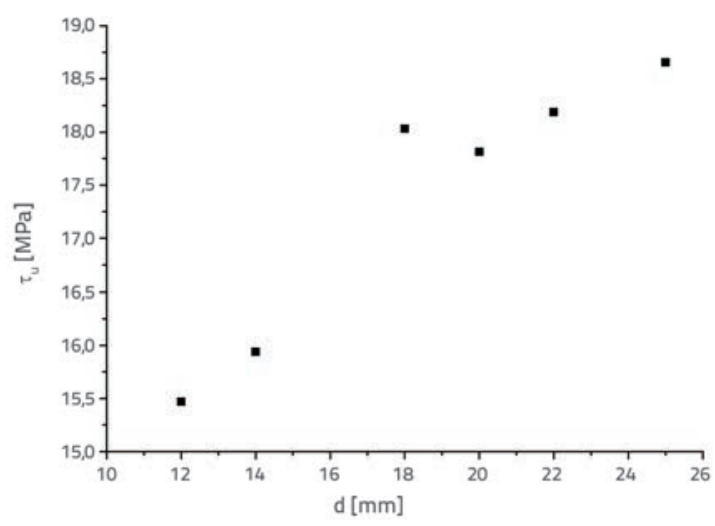

Figure 14. Variation of $\tau_{u}$ with $d$ of specimens that failed by grout-bar bond failure
It can be seen that the average ultimate lapping bond stress, , increases as the bar diameter, $d$, increases. As the bar diameter increases, the confinement stress generated by the sleeve wall increases, leading to an increase in the average ultimate lapping bond stress, $\tau_{i}$

According to test results, the performance of the connector can be affected by the tensile strength of grout, bar diameter, sleeve internal diameter, and lap length. Equation (7) explaining the interrelationship between the average ultimate lapping bond stress, $\tau_{u^{\prime}}$ tensile strength of grout, $R_{t^{\prime}}$ relative lap length, $d / L$, and relative bar diameter, $d / D$ is derived by the linear regression method to evaluate performance of the connector.

$\tau_{u}=\left(3.86 \frac{d}{D}-17.51 \frac{d}{L}+4.90\right) R_{t}$

where:

$\tau_{u}$ is the average ultimate lapping bond stress $\left(\mathrm{N} / \mathrm{mm}^{2}\right), R_{t}$ is the tensile strength of grout $\left(\mathrm{N} / \mathrm{mm}^{2}\right), d$ is the bar diameter $(\mathrm{mm})$, $D$ is the sleeve internal diameter $(\mathrm{mm})$ and $L$ is the lap length (mm).

For verification purposes, the parameters used in the experiments are substituted into Equation (7) and the experimental results are weighed against the predicted outcomes to acquire the reliability of the empirical equation, as shown in Table 4. It can be seen that the proposed equation provides a reliable prediction, with the reliability ratios, $R_{\mathrm{r}^{\prime}}$ close to 1.0 .

Table 4. Comparison of calculated and experimental values of average ultimate lapping bond stress

\begin{tabular}{|c|c|c|c|c|c|c|}
\hline Specimens & $\begin{array}{c}\mathbf{R}_{\mathrm{t}} \\
{[\mathrm{MPa}]}\end{array}$ & $d / D$ & $d / L$ & $\left(\tau_{u}\right)_{\exp }$ & $\left(\tau_{\mathrm{u}}\right)_{\mathrm{cal}}$ & $R_{\mathrm{r}}$ \\
\hline $12-96$ & \multirow{8}{*}{4.63} & 0.17 & 0.125 & 15.46 & 15.65 & 0.99 \\
\hline $14-112$ & & 0.20 & 0.125 & 15.93 & 16.16 & 0.99 \\
\hline $18-100^{*}$ & & 0.26 & 0.18 & 12.69 & 12.73 & 1.00 \\
\hline $18-144$ & & 0.26 & 0.125 & 18.01 & 17.18 & 1.05 \\
\hline $18-150^{*}$ & & 0.26 & 0.12 & 17.32 & 17.59 & 0.98 \\
\hline $20-160$ & & 0.29 & 0.125 & 17.83 & 17.69 & 1.01 \\
\hline $22-176$ & & 0.31 & 0.125 & 18.20 & 18.20 & 1.00 \\
\hline $25-200$ & & 0.36 & 0.125 & 18.66 & 18.94 & 0.98 \\
\hline
\end{tabular}

\section{Recommended lap length}

The critical lap length, I, is an important parameter for the design of a grouted sleeve lapping connector. At length I, when bar tensile fracture out of the sleeve and bar-grout slippage occur at the same time, the bar-grout bond capacity equals the tensile capacity of the overlapped bars, and Equation (8) and Equation (9) are tenable. 
$\tau_{u, I} \pi d l=f_{u, b} \frac{1}{4} \pi d^{2}$

$\tau_{u, l}=\left(3.86 \frac{d}{D}-17.51 \frac{d}{l}+4.90\right) R_{t}$

where

$\tau_{u, l}$ is the average ultimate lapping bond stress at the critical lap length $\left(\mathrm{N} / \mathrm{mm}^{2}\right), d$ is the bar diameter $(\mathrm{mm})$, I is the critical lap length $(\mathrm{mm}), f_{u, b}$ is the bar ultimate tensile strength $\left(\mathrm{N} / \mathrm{mm}^{2}\right)$, $D$ is the sleeve internal diameter $(\mathrm{mm})$, and $R_{t}$ is the tensile strength of grout $\left(\mathrm{N} / \mathrm{mm}^{2}\right)$.

Combining Equation (8) with Equation (9) yields Equation (10).

$I=\frac{\frac{f_{u, b}}{R_{t}}+70.04}{\frac{15.44}{D}+\frac{19.6}{d}}$

Substituting the test values of $f_{u, b^{\prime}} R_{t^{\prime}} D$ and $d$ into Equation (10), we acquire the values of the critical lap length, $I$. The results are shown in Table 5.

The lap length of specimens that failed by bar-grout slip is smaller than I, whereas the lap length of specimens that failed by bar fracture is larger than $I$. Hence, a range of values can be acquired according to results shown in Table 3 to estimate the value of $l$, as shown in Table 5.

Table 5. Estimation of critical lap length l, unit: mm

\begin{tabular}{|c|c|c|c|}
\hline $\boldsymbol{d}$ & $\boldsymbol{L}_{\text {calculated }}$ & $\boldsymbol{L}_{\text {range }}$ & $\boldsymbol{L}_{\text {recommended }}$ \\
\hline 12 & 105 & $96-120$ & 120 \\
\hline 14 & 122 & $112-140$ & 140 \\
\hline 16 & 136 & $<128$ & 160 \\
\hline 18 & 159 & $144-180$ & 180 \\
\hline 20 & 171 & $160-200$ & 200 \\
\hline 22 & 174 & $176-220$ & 220 \\
\hline 25 & 198 & $200-250$ & 250 \\
\hline
\end{tabular}

Almost all calculated values fall within the ranges of experimental values, except the calculated value of the bar 16 $\mathrm{mm}$ in diameter, $136 \mathrm{~mm}$, which is larger than the maximum value of the corresponding range, $128 \mathrm{~mm}$, and the calculated values of the bars with diameters $22 \mathrm{~mm}$ and $25 \mathrm{~mm}$ are slightly smaller than the minimum values of the corresponding range, indicating a relatively high reliability of Equation (9).

All specimens with lap lengths 10 and 12.5 times the bar diameter meet the evaluation criteria for strength. Moreover, the working performance of the connector is poorer in the structural form of specimens where bars are placed clinging to each other. Based on experimental results and the above analysis, the recommended lap length of the grouted sleeve lapping connector is 10 times the overlapped bar diameter, as shown in Table 5.

\section{Conclusions}

Compared to the bare bar in tension, the yield plateau of the specimens was not fully developed, due to deflection of the specimens.

The ultimate tensile capacity of specimens that failed by bar fracture was close to the average tensile capacity of the control bar with the same bar diameter. All specimens with lap lengths 10 and 12.5 times the bar diameter meet the evaluation criteria according to which the tensile strength of the splice must be at least $125 \%$ of the specified yield strength of the spliced bar (ACl-318 12.14.3.2).

The bar tensile failure and the bar-grout bond failure are the typical modes of grouted sleeve lapping connectors. Failure modes of the grout-sleeve slip and sleeve tensile failure were not shown.

For specimens with the same bar diameter that fail by bar fracture, the transverse confinement provided by the sleeve wall decreases as the lap length increases. For specimens that fail by bar-grout bond failure, an increase in the bar diameter leads to an increase in the confinement stress generated by the sleeve wall, and the average ultimate lapping bond stress increases as the bar diameter increases.

Equation (7), which is used to estimate the ultimate lapping bond stress, and Equation (10), which aims to calculate the critical lap length, provide the basis for the design and evaluation of the grouted sleeve lapping connector.

Using advantages of confinement effects generated from the sleeve, the recommended lap length can be as short as ten times the bar diameter, which is approximately $20 \%$ of the tension lap length recommended by $\mathrm{ACl}-318$ (at least 50 times the bar diameter).

As the testing was conducted on a specific quality of grout characterized by the flexural strength, compressive strength and tensile strength of $11.4 \mathrm{MPa}, 62.9 \mathrm{MPa}$ and 4.63 MPa, respectively, and as the sleeve $70 \mathrm{~mm}$ in internal diameter and $3 \mathrm{~mm}$ in thickness was used, the findings are applicable for the specified grout quality and sleeve geometry only.

Due to some problems identified during the testing of connectors (i.e. rotation of the connector due to tensile loading), it is necessary to tests seismic behaviour of pre-cast shear walls with vertical reinforcements spliced by a grouted sleeve lapping connector, to evaluate the operating performance of the grouted sleeve lapping connector used in the structures. 


\section{REFERENCES}

[1] Yee, A.A.: Splice sleeve for reinforcing bars. US Pat. 3,540,763; 1968.

[2] New precast prestressed system saves money in Hawaii hotel. PCl Journal, 18 (1973) 3, pp.10-13.

[3] Ling, J.H., Abd. Rahman, A.B., Ibrahim, I.S., Abdul Hamid, Z.: Behaviour of grouted pipe splice under incremental tensile load, Construction and Building Materials, 33 (2012), pp. 90-98, https:// doi.org/10.1016/j.conbuildmat.2012.02.001

[4] Ling, J.H., Abd. Rahman, A.B., Ibrahim, I.S.: Feasibility study of grouted splice connector under tensile load. Construction and Building Materials, 50 (2014), pp. 530-539, https://doi. org/10.1016/j.conbuildmat.2013.10.010

[5] Alias, A., Zubir, M.A., Shahid, K.A., RAhman, A.B.A.: Structural Performance of Grouted Sleeve Connectors with and without Transverse Reinforcement for Precast Concrete Structure, Procedia Engineering, 53 (2013), pp.116-123, https://doi. org/10.1016/j.proeng.2013.02.017

[6] Hosseini, S., Abd. Rahman, A.B.: Analysis of spiral reinforcement in grouted pipe splice connectors. Gradevinar, 65 (2015) 6, pp. 537 546, https://doi.org/10.14256/JCE.1163.2014

[7] Sayadi, A.A., Rahman, A.B.A., Jumaat, M.Z.B., Johnson Alengaram, U., Ahmad, S.: The relationship between interlocking mechanism and bond strength in elastic and inelastic segment of splice sleeve, Construction and Building Materials, 55 (2014), pp. 227237, https://doi.org/10.1016/j.conbuildmat.2014.01.020

[8] Gregel, J.J., Colarusso, L.J.: Reinforcing bar splice and method. US Pat. 6,532,711; 2003

[9] Albrigo, J., Ricker, E. D., Colarusso, L.J.: Reinforcing bar splice and system for forming precast concrete members and structures. US pat. 5,468,524; 1995

[10] Yee, A.A.: Splice sleeve for reinforcing bars with cylindrical shell. US Pat. 4,627,212; 1986

[11] Yee, A.A.: Wire cage-type splice sleeve for reinforcing bars. US Pat. 3,552,787; 1971.

[12] Mochizuki, H., Nihei, T.: Mortar grout splice sleeve for reinforcing bars. US Pat. 5,974,761; 1999

[13] Albrigo, J., Ricker, E.D., Colarusso, L.J.: Method of forming concrete structures with a grout splice sleeve which has a threaded connection to a reinforcing bar, US pat. 5366671, 1994.

[14] Dahl, K.L.: High strength grouted pipe coupler. US Pat.6,679,024 2004.

[15] Lancelot III, H.B.: Combination mechanical/grout sleeve coupling for concrete reinforcement bars, US pat. 5383740 A, 1995.

[16] Chen, Y.G., Liu, J.B., Guo, Z. X., Zhang, J.X.: Test on seismic performance of precast shear wall with reinforcements grouted in holes and spliced indirectly in horizontal connections, Journal of Harbin Institute of Technology, 45 (2013) 6, pp. 83-89.
[17] Jiang, H., Zhang, H., Liu, W., Yan, H.: Experimental study on plugin filling hole for steel bar lapping of precast concrete, Journal of Harbin Institute of Technology, 43 (2011) 10, pp. 18-23.

[18] Zhang, H.S.: Experimental study on plug-in filling holes for lapjoint of steel bar of PC concrete structure, Harbin Institute of Technology, 2009.

[19] Eligehausen, R., Popov, E.P., Bertero, V.V.: Local bond stress-slip relationships of deformed bars under generalized excitations, University of California, 1982.

[20] Soroushian, P., Choi, K.B., Park, G.H., Aslani, F.: Bond of Deformed Bars to Concrete: Effects of Confinement and Strength of Concrete, ACI Material Journal, pp. 227-232, 1991.

[21] Rizkalla, S.H., Hwang, L.S., El Shahawi, M.: Transverse reinforcement effect on cracking behaviour of R.C. members; Canadian Journal of Civil Engineering, 10 (1983) 4, pp. 566-581.

[22] Einea, A., Yamane, T., Tadros, M.K.: Grout-filled pipe splices for precast concrete construction, Precast/Prestress Concrete Institute Journal, 40 (1995) 1, pp. 82-93.

[23] Loh, H.Y.: Development of grouted splice sleeve and its performance under axial tension, Universiti Teknologi Malaysia, 2008.

[24] Ling, J.H.: Behaviour of grouted splice connection in precast concrete wall subjected to tensile, shear and flexual loads, Universiti Teknologi Malaysia, 2011.

[25] Yu, Q.: A new confined lapping sleeve. CN 204238449 U, 2015

[26] Building Code Requirements for Structural Concrete and Commentary, American Concrete Institute, 2011.

[27] Soudki, K.A., Rizkalla, S.H., Leblanc, B.: Horizontal connections for precast concrete shear walls subjected to cyclic deformations part1: mild steel connections, PCI Journal, 41 (1995) 1, pp. 78-96.

[28] Lutz, L.A., Peter, G.: Mechanics of Bond and Slip of Deformed Bars in Concrete, ACI Journal, 64 (1967) 10, pp.711-721.

[29] Tastani, S.P., Brokalaki, E., Panatazopoulou, S.J.: State of bond along lap splices, Journal of Structural Engineering, 2015, https:// doi.org/10.1061/(ASCE)ST.1943-541X.0001243

[30] Orangun, C.O., Jirsa, J.O., Breen, J. E.: A reevaulation of test data on development length and splices, ACl Journal Proceedings, 74 (1977) 3, pp. 114-122.

[31] Tepfers, R.: Cracking of concrete cover along anchored deformed reinforcing bars, Magazine of Concrete Research, 31 (1979) 106, pp. 3-12.

[32] Tastani, S., Pantazopoulou, S.: Behavior of corroded bar anchorages, ACI Structural Journal, 104 (2007) 6, pp. 756-766. 